\title{
Effect of species, breed, and age on bacterial load in bovine and bubaline semen
}

\author{
Chandrahas Sannat ${ }^{1}$, Ajit Nair ${ }^{2}$, S. B. Sahu ${ }^{2}$, S. A. Sahasrabudhe ${ }^{2}$, Ashish Kumar ${ }^{1}$, Amit Kumar Gupta ${ }^{1}$ and R. K. Shende ${ }^{1}$ \\ 1. Department of Veterinary Microbiology, College of Veterinary Science \& A.H., Chhattisgarh Kamdhenu \\ Vishwavidayalaya, Anjora, Durg Chhattisgarh, India; 2. Central Semen Station, Livestock Development Department, \\ Government of Chhattisgarh, Anjora, Durg, Chhattisgarh, India. \\ Corresponding author: Chandrahas Sannat, e-mail: csannat@rediffmail.com, \\ AN: Ajitnair1971@gmail.com, SBS: Sahusb@ymail.com, SAS: Oic2css@gmail.com, AK: Ashishvetdoc@gmail.com, \\ AKG: Dramitkumaragrahari2009gmail.com, RKS: Rshende786@rediffmail.com \\ Received: 14-11-2014, Revised: 02-03-2015, Accepted: 10-03-2015, Published online: 09-04-2015
}

doi: 10.14202/vetworld.2015.461-466. How to cite this article: Sannat C, Nair A, Sahu SB, Sahasrabudhe SA, Kumar A, Gupta AK, Shende RK (2015) Effect of species, breed and age on bacterial load in bovine and bubaline semen, Veterinary World 8(4): 461-466.

\begin{abstract}
Aim: The present study was conducted to investigate the effect of species, breed and age on bacterial load in fresh and frozen semen of Cattle and Buffalo bull.

Materials and Methods: Present study covered 56 cow and 10 buffalo bulls stationed at Central Semen Station Anjora, Durg (Chhattisgarh). Impact of breeds on bacterial load in semen was assessed using six breeds of cattle viz. Sahiwal, Gir, Red Sindhi, Tharparkar, Jersey and Holstein Friesian (HF) cross. Cow bulls were categorized into four different groups based on their age ( $<4$ years, 4-5 years, 5-6 years and $>6$ years) to study variation among age groups. Bacterial load was measured in fresh and frozen semen samples from these bulls using the standard plate count (SPC) method and count was expressed as colony forming unit (CFU) per ml of semen.

Results: Higher bacterial load was reported in fresh $\left(2.36 \times 10^{4} \pm 1943 \mathrm{CFU} / \mathrm{ml}\right)$ and frozen $(1.00 \times 10 \pm 90 \mathrm{CFU} / \mathrm{ml}) \mathrm{semen}$ of cow bulls as compared to buffalo bulls $\left(1.95 \times 10^{4} \pm 2882\right.$ and $7.75 \times 10^{2} \pm 160 \mathrm{CFU} / \mathrm{ml}$ in fresh and frozen semen, respectively). Jersey bull showed significantly higher bacterial count $(\mathrm{p}<0.05)$ both in fresh $\left(4.07 \times 10^{4} \pm 13927 \mathrm{CFU} / \mathrm{ml}\right)$ and frozen $\left(1.92 \times 10^{3} \pm 178 \mathrm{CFU} / \mathrm{ml}\right)$ semen followed by HF cross, Sahiwal, Gir, Red Sindhi and Tharparkar bull. Bulls aged $<4$ years and more than 6 years yielded increased bacterial load in their semen. Although a minor variation was reported between species and among age groups, no significant differences were measured.
\end{abstract}

Conclusion: Bacterial load in semen did not differ significantly between species and age groups; however significant variation was reported among different breeds. Bulls of Jersey breed showed significantly higher bacterial load in semen as compared to the crossbred and indigenous bull.

Keywords: age group, bacterial load, breed, buffalo bulls, cow bulls, semen.

\section{Introduction}

Cattle and buffalo play an important role in rural livestock production by providing milk, meat, and work draft forces. About $80 \%$ of total cattle population consisted of the low producing nondescript animal. Breeding policy has been set up for conservation and development of these animals by Government of India as well respective states of India. Though breeding policy varies with region and locality specific features such as climate condition, feed and fodder availability, and livestock management practices, two important strategies for breed improvement included upgrading with indigenous breeds and crossbreeding with exotic breeds. Genetic improvement in these animals is carried out by artificial insemination technique using cryopreserved semen of potential cattle and buffalo bulls. Apart from providing desired genetic characteristics, semen could act as a vehicle for the wide range of undesirable pathogens [1]. Organisms can be

Copyright: The authors. This article is an open access article licensed under the terms of the Creative Commons Attributin License (http://creativecommons.org/licenses/by/2.0) which permits unrestricted use, distribution and reproduction in any medium, provided the work is properly cited. acquired either from infection in animals, preputial sheath or from the environment during collection, processing or packaging of semen. The bacterial contaminants of semen have been a major concern for most semen production laboratories as it adversely affects the semen quality [2] and hence the subsequent fertility [3]. Hence, the success of AI program depends on quality semen production in the laboratory.

To ensure clean semen production routine, surveillance of bacterial load in semen is needed. Lot of workers have worked on bacteriological analysis of semen both of cow bulls [4-7] and buffalo bulls $[5,8,9]$ and also reported minor variation among species. Based on breeding policies of respective states, different breeds of cattle and buffalo are used for genetic improvement. Bacterial load in semen may vary among individual bulls of similar breed or between breeds also [4]. Although, bacterial load in semen was being evaluated in different cattle breeds, i.e., Holstein Friesian (HF) [10], crossbred cattle [6], Jersey and Guernsey [4], Hereford [11], Sahiwal [12] and Gir [5], none of the report presented comparative analysis between breeds. Apart from this, bulls used 
for semen collection in semen station belong to different age group and as per norms of minimum standard protocol for production of bovine semen, semen collection may continue from bulls up to the maximum age of 10 years [13]. Previously, attempt was already made to establish a correlation between age of the bull and microbial load in semen [11].

Hence, a better knowledge of the effect of species, breed, and age on semen microbes can help the AI industry to adapt a standard management of bulls to improve semen output. Taking above facts into consideration, an attempt was made to investigate the influence of species, breed, and various age groups on bacterial load in fresh and frozen semen of cow and buffalo bull stationed at Central Semen Station, Anjora, Durg (Chhattisgarh).

\section{Materials and Methods}

\section{Ethical approval}

Ethical approval was not necessary. On routine semen collection days, samples were taken from animals. Proper ethical considerations related to animal handling were observed and ensuring not to cause any injury during sampling.

\section{Bulls under study}

A total of 56 cow and 10 buffalo bulls stationed at central semen station Anjora, Durg (Chhattisgarh) were taken into study. Due to availability of only one breed and less population size in various age groups of buffalo bull, investigation regarding variation between breeds, and age groups was not conducted for buffalo bulls and only cow bulls were analyzed for the same. Semen samples collected from six breeds of cattle, i.e. Sahiwal, Gir, Red Sindhi, Tharparkar, HF cross and Jersey breed were evaluated for bacterial load to assess the variation among breeds. Semen collection starts at age when bull reaches sexual maturity and continued for a maximum of 5-6 years [13]. As per the availability of bulls of different age groups, bulls under study were categorized into four groups viz. Below 4 years, 4-5 years, 5-6 years and above 6 years. During the course of study, all bulls were being maintained under similar feeding and managemental practices.

\section{Screening of bulls for communicable diseases}

All bulls were being routinely screened (every $1 / 2$ yearly) for major contagious diseases before their entry to semen station. As per OIE guidelines and minimum standard protocol for production of bovine semen [13], breeding bulls were tested for bacterial diseases namely tuberculosis, paratuberculosis, brucellosis and genital campylobacteriosis by an accredited agency i.e. Western Region Disease Diagnostic Laboratory, Pune. Bulls under the present study were found negative for above communicable diseases.

\section{Collection and processing of semen samples}

Semen samples were collected by means of sterile artificial vagina using routine collection technique [14]. Strict aseptic measures were practiced during collection and handling of semen samples. Physical characteristics of fresh ejaculates are summarized in Table-1. Fresh semen samples were processed immediately for bacteriological examination within $1 \mathrm{~h}$ after collection. Frozen semen straws were prepared using standard processing techniques. Conventional antibiotics, i.e. streptomycin sulfate $(100 \mu \mathrm{g} / \mathrm{ml})$ and penicillin $(100 \mathrm{IU} / \mathrm{ml})$ were added in the semen extender to overcome bacterial growth [15].

\section{Determination of bacterial load in semen}

The bacterial load in the semen samples was measured using standard plate count (SPC) method [16]. Culture media and reagents of HiMedia were used throughout the study.

\section{Fresh semen}

Tenfold serial dilution of the semen sample $(1: 10,1: 100,1: 1000$ and 1:10000) was made in sterile nutrient broth. Inoculums size of $0.05 \mathrm{ml}$ from each dilution was mixed thoroughly with molten SPC agar (previously held in the water bath at $50^{\circ} \mathrm{C}$ ) and poured into sterile petri dish plates. Separate plates were used with each dilution and two SPC agar plates were taken for a single batch of semen. Agar was allowed to set and then incubated at $37^{\circ} \mathrm{C}$ for $72 \mathrm{~h}$. Colonies per plate were read and counted with the help of colony counter. Colony forming unit (CFU) per ml

Table-1: Physical characteristics of bull semen.

\begin{tabular}{|c|c|c|c|c|c|c|}
\hline Breed & $\begin{array}{l}\text { Number } \\
\text { of bulls }\end{array}$ & $\begin{array}{c}\text { Number of } \\
\text { ejaculates } \\
\text { tested }\end{array}$ & Color & $\begin{array}{l}\text { Volume } \\
(\mathrm{ml})\end{array}$ & $\begin{array}{c}\text { Sperm } \\
\text { concentration } \\
\text { (millions/ml) }\end{array}$ & $\begin{array}{c}\text { Progressive } \\
\text { motility } \\
(\%)\end{array}$ \\
\hline Sahiwal & 13 & 52 & Milky creamy and creamy & $4.5 \pm 0.29$ & $1252 \pm 71$ & $73 \pm 2.1$ \\
\hline Gir & 8 & 32 & $\begin{array}{l}\text { Milky creamy, creamy, } \\
\text { and slightly yellowish }\end{array}$ & $5.3 \pm 0.25$ & $1268 \pm 85$ & $71 \pm 2.1$ \\
\hline Red Sindhi & 9 & 36 & Milky creamy and creamy & $5.4 \pm 0.34$ & $1359 \pm 134$ & $73 \pm 1.3$ \\
\hline Tharparkar & 8 & 32 & Milky creamy to creamy & $4.7 \pm 0.31$ & $1449 \pm 115$ & $74 \pm 0.9$ \\
\hline Jersey & 7 & 28 & $\begin{array}{l}\text { milky creamy to creamy } \\
\text { and watery in few cases }\end{array}$ & $4.9 \pm 0.23$ & $1066 \pm 73$ & $75 \pm 2.3$ \\
\hline HF cross & 7 & 28 & $\begin{array}{l}\text { Milky creamy to creamy } \\
\text { and watery in few cases }\end{array}$ & $7.6 \pm 0.33$ & $1008 \pm 92$ & $74 \pm 1$ \\
\hline Murrah & 10 & 40 & Milky creamy to creamy & $3.7 \pm 0.27$ & $1051 \pm 63$ & $79 \pm 1.7$ \\
\hline
\end{tabular}

$\mathrm{HF}=$ Holstein Friesian 
of sample was calculated using the formula: $\mathrm{CFU} / \mathrm{ml}$ of sample $=$ No. of CFU's $\times$ dilution $\times 2$.

\section{Frozen semen}

Frozen semen straws were thawed by placing it in the water bath at $37^{\circ} \mathrm{C}$ for $30 \mathrm{~s}$. After drying, straws were disinfected by $70 \%$ ethanol and both sides of frozen semen straw has been broken using a sterile scissor, in order to take a drop of semen after neglecting the first drop. For each sample, four numbers of French mini straws $(0.25 \mathrm{ml})$ were thawed, to obtain inoculums size of $0.5 \mathrm{ml}$. Then, samples were serially diluted in sterile nutrient broth and processed for bacterial load as per the technique mentioned above for fresh semen.

\section{Data recording and statistical analysis}

Data were expressed as means ( \pm standard error of the mean) $\mathrm{CFU} / \mathrm{ml}$ of semen and analyzed by applying general linear model for factorial experiments using SPSS computer software package (Version 16.0.0.247 2007 ). Duncan's multiple range tests was done to make specific treatment comparisons for values that were found significant by ANOVA.

\section{Results}

\section{Species wise variation of bacterial load}

Present study reported bacterial load of $2.36 \times 10^{4} \pm 1943$ and $1.95 \times 10^{4} \pm 2882 \mathrm{CFU} / \mathrm{ml}$ in fresh semen of cattle and buffalo, respectively. However, bacterial load observed in frozen semen of cattle and buffalo were $1.00 \times 10^{3} \pm 90$ and $7.75 \times 10^{2} \pm 160 \mathrm{CFU} / \mathrm{ml}$, respectively (Table-2). Though present investigation reported lower bacterial load in fresh and frozen semen of buffalo bull as compared to cow bull, no significant variation was observed between species $(\mathrm{p}>0.05)$.

\section{Breed wise variation of bacterial load}

Bacterial load observed in semen from different breeds of cattle is shown in Table-3. Significantly higher bacterial load was reported in fresh $\left(4.07 \times 10^{4} \pm 13927 \mathrm{CFU} / \mathrm{ml}\right)$ as well frozen $\left(1.92 \times 10^{3} \pm 178 \mathrm{CFU} / \mathrm{ml}\right)$ semen of Jersey bull followed by HF cross, Sahiwal, Gir, Red sindhi, Tharparkar in case of fresh semen and HF cross, Gir, Sahiwal, Red sindhi and Tharparkar in case of frozen semen. Bacterial load in fresh semen of Jersey bull differed highly significantly from Tharparkar and Red Sindhi $(\mathrm{p}<0.01)$ and significantly with Sahiwal and Gir bull $(\mathrm{p}<0.05)$ while no significant variation was seen between Jersey and HF cross. However, bacterial load in frozen semen of Jersey bull differed highly significantly $(p<0.01)$ from all other breeds under study. In frozen semen, Gir showed higher bacterial load as compared to Sahiwal bull, but did not differ significantly $(p>0.05)$.

\section{Influence of age on bacterial load}

Non-significant differences ( $p>0.05)$ of bacterial load was noted between different age groups. However, comparatively higher bacterial load was observed in semen of young bulls (aged below 4 years) followed by older bulls (above 6 years). Bulls aged 4-5 and 5-6 years yielded relatively lower bacterial load in their semen (Table-4).

\section{Discussion}

\section{Species wise variation of bacterial load}

Variation of bacterial load in semen of cattle and buffalo was supported by Hasan et al.[12] and present finding may be compared with observation of Jaisal et al. [5], who also reported increased bacterial count $\left(5 \times 10^{3}-5.6 \times 10^{3} \mathrm{CFU} / \mathrm{ml}\right)$ in fresh semen of cow bull than buffalo bull $\left(4.1 \times 10^{3}-1.8 \times 10^{4} \mathrm{CFU} / \mathrm{ml}\right)$. Likewise, Gunsalus et al. [17], Meredith [18], Brown et al. [11], Miller and Salisbury [19] and Almquist et al. [4] also observed higher bacterial load of $2.2 \times 10^{4}, 36.5 \times 10^{4}, 2.31 \times 10^{4}, 3 \times 10^{5}-3 \times 10^{7}$ and $1 \times 10^{2}-3 \times 10^{7} \mathrm{CFU} / \mathrm{ml}$ respectively, in fresh semen of cow bull. Lower bacterial load reported in frozen semen doses were due to the effect of added antibiotics [15]; however in a report [20] it was mentioned that $13 \%$ of isolated bacteria from semen were resistant to penicillin and streptomycin, the most common antibiotic combination used in semen diluents.

Bacterial load reported in frozen semen of cow bull in present finding is in agreement with the findings of Kumar et al. [21], Patel et al.[6] and Wierzbowski et al. [22] who also reported similar bacterial load of $1.1 \times 10^{2}, 1.26-5.9 \times 10^{4}$ and $1.1 \times 10^{3} \mathrm{CFU} / \mathrm{ml}$, respectively in frozen semen. Likewise present observation, similar bacterial count of $0.73 \times 10^{2} \mathrm{CFU} / \mathrm{ml}$ [8]; $1.0-5.0 \times 10^{2} \mathrm{CFU} / \mathrm{ml}$ [5] and $0.41 \times 10^{2} \mathrm{CFU} / \mathrm{ml}$ [7] were reported in frozen semen of buffalo bull too. In contrast to present finding, Rathnamma et al.[10] reported higher bacterial load $\left(5.05-171.4 \times 10^{3} \mathrm{CFU} / \mathrm{ml}\right)$ in frozen semen of buffalo bull than that of cow bull $\left(0.81-39 \times 10^{3} \mathrm{CFU} / \mathrm{ml}\right)$. In a study [23], higher incidence of microbial population were recorded in preputial cavity of breeding cow bull as compared to buffalo bull, which might account for higher bacterial load in semen of cow bull than buffalo bull. Furthermore, lower bacterial count in

Table-2: Species wise variation of bacterial load in semen.

\begin{tabular}{lcccc}
\hline Species & $\begin{array}{c}\text { Number } \\
\text { of bulls }\end{array}$ & $\begin{array}{c}\text { Number of } \\
\text { ejaculate tested }\end{array}$ & \multicolumn{2}{c}{ CFU/mI (mean \pm SEM) } \\
\cline { 4 - 5 } & 56 & 224 & Fresh semen & Frozen semen \\
\hline Cattle & 10 & 40 & $2.36 \times 10^{4} \pm 1943^{\mathrm{a}}$ & $1.00 \times 10^{3} \pm 90^{\mathrm{a}}$ \\
Buffalo & 0 & $1.95 \times 10^{4} \pm 2882^{\mathrm{a}}$ & $7.75 \times 10^{2} \pm 160^{\mathrm{a}}$ \\
\hline
\end{tabular}

Note: Values having similar superscript in a column differ non-significantly $(p>0.05)$, SEM=Standard error of mean, $\mathrm{CFU}=$ Colony forming unit 
Table-3: Breed wise variation of bacterial load in cow bull semen.

\begin{tabular}{lcccc}
\hline Breed & $\begin{array}{c}\text { Number } \\
\text { of bulls }\end{array}$ & $\begin{array}{c}\text { Number of } \\
\text { ejaculates tested }\end{array}$ & \multicolumn{2}{c}{ CFU/mI (mean \pm SEM) } \\
\cline { 4 - 5 } & 13 & 52 & Fresh semen & Frozen semen \\
\hline Sahiwal & 8 & 32 & $2.36 \times 10^{4} \pm 2604^{\mathrm{ab}}$ & $9.61 \times 10^{2} \pm 138^{\mathrm{a}}$ \\
Gir & 9 & 36 & $2.34 \times 10^{4} \pm 2161^{\mathrm{ab}}$ & $1.09 \times 10^{3} \pm 240^{\mathrm{a}}$ \\
Tharparkar & 8 & 32 & $1.75 \times 10^{4} \pm 3975^{\mathrm{a}}$ & $6.11 \times 10^{2} \pm 172^{\mathrm{a}}$ \\
Red sindhi & 7 & 28 & $1.90 \times 10^{4} \pm 5042^{\mathrm{a}}$ & $6.56 \times 10^{2} \pm 226^{\mathrm{a}}$ \\
Jersey & 7 & 28 & $4.07 \times 10^{4} \pm 13927^{\mathrm{b}}$ & $1.92 \times 10^{3} \pm 178^{\mathrm{b}}$ \\
HF cross & 7 & $2.42 \times 10^{4} \pm 3023^{\mathrm{ab}}$ & $1.10 \times 10^{3} \pm 224^{\mathrm{a}}$ \\
\hline
\end{tabular}

Note: Values with different superscript in a column differ significantly, SEM=Standard error of mean, HF=Holstein

Friesian, CFU=Colony forming unit

Table-4: Effect of age of cow bull on bacterial load in their semen.

\begin{tabular}{lcccc}
\hline Age group & $\begin{array}{c}\text { Number } \\
\text { of bulls }\end{array}$ & $\begin{array}{c}\text { Number of } \\
\text { ejaculates tested }\end{array}$ & \multicolumn{2}{c}{ CFU/mI (mean \pm SEM) } \\
\cline { 4 - 5 } & 13 & 26 & Fresh semen & Frozen semen \\
\hline$<4$ years & 19 & 38 & $2.82 \times 10^{4} \pm 4006^{\mathrm{a}}$ & $1.21 \times 10^{3} \pm 180^{\mathrm{a}}$ \\
4-5 years & 12 & 24 & $2.35 \times 10^{4} \pm 5264^{\mathrm{a}}$ & $7.36 \times 10^{2} \pm 124^{\mathrm{a}}$ \\
5-6 years & 12 & 24 & $1.92 \times 10^{4} \pm 2805^{\mathrm{a}}$ & $1.04 \times 10^{3} \pm 253^{\mathrm{a}}$ \\
More than 6 years & 12 & $2.45 \times 10^{4} \pm 3438^{\mathrm{a}}$ & $1.14 \times 10^{2} \pm 177^{\mathrm{a}}$ \\
\hline
\end{tabular}

Note: Values having similar superscript in a column differ non-significantly $(p>0.05), C F U=$ Colony forming unit, $\mathrm{SEM}=$ Standard error of mean

buffalo semen may be correlated with higher semen mass activity, higher individual sperm motility, and higher post-thaw motility of buffalo semen as compared to cattle semen [24].

\section{Breed wise variation of bacterial load}

Present study reported significantly higher bacterial count in exotic and crossbred cattle than indigenous breeds. Different coworkers have evaluated bacterial load in different breeds, but none of them have analyzed variation between breeds. In a comparative study between three breeds, marked variation of bacterial load was reported between semen samples from different bulls [4]; in which Guernsey, HF and Jersey bulls yielded bacterial load of $26 \times 10^{4}, 13 \times 10^{4}$ and $5.3 \times 10^{4} \mathrm{CFU}$ per $\mathrm{ml}$ of fresh semen, respectively. As per present investigation, higher count of $1 \times 10^{3}-22 \times 10^{6} \mathrm{CFU} / \mathrm{ml}$ [17] and $3 \times 10^{5}-3 \times 10^{7} \mathrm{CFU} / \mathrm{ml}$ [19] was reported in crossbred cattle. More or less similar results were reported in fresh semen of HF [10], Gir [5] and Sahiwal semen [12].

Bacterial load in frozen semen of HF cross may be compared with observation of Wierzbowski et al. [22] and Patel et al. [6] who reported bacterial count of $1.1 \times 10^{3}$ and $1.9 \times 10^{3} \mathrm{CFU} / \mathrm{ml}$, respectively. In contrast, less bacterial load of $1.1 \times 10^{2}$ and $1.62 \times 10^{2} \mathrm{CFU} / \mathrm{ml}$ was reported by Kumar et al. [21] and Patel and Patel. [25], respectively in frozen semen of crossbred cattle and $0.89 \times 10^{2} \mathrm{CFU} / \mathrm{ml}$ by Hassan et al. [12] in Sahiwal bull. In another group of study $[6,10,25]$, lower bacterial load was reported in frozen semen of HF bull.

Wide variation of bacterial count in semen samples between different bulls and breeds might be due to day-to-day- fluctuation which occurred in the bacterial content of semen collected from apparently healthy animals. In a study [11], it was reported that concentration of natural inhibitors in seminal plasma varies from bull to bull and among breeds and higher concentration of inhibitors was reported in seminal plasma of HF than Hereford cattle. Significant differences of bacterial load in semen of different breeds might be correlated with the level of cytokine expression in cells of different breeds leading to the inherent resistance against infection [26]. The preputial orifice of bull may be a major source of the different types of bacteria found in soil, bedding, and manure [27]. It was reported that Gir bulls were being predisposed to prolapse of the preputial sheath thus exposed to infection, which might accounts for higher bacterial count in semen [28]. In present investigation, it was observed that newly purchased young bulls $(08$ out of 14 bulls) in Sahiwal group showed increased bacterial load in their semen, which might account for overall higher load in Sahiwal bull as compared to other indigenous breeds. Higher bacterial load in exotic and crossbred cattle than indigenous breeds could be explained. Variations in bacterial load are caused by several factors such as cleanliness, ambient temperature, relative humidity, and photoperiod [29]. The ambient temperatures of $35-40^{\circ} \mathrm{C}$ with a relative humidity of $35-45 \%$ reduced semen quality significantly, as bacterial population in the semen grow best at $20-40^{\circ} \mathrm{C}$ [30]. Durg, being a tropical and sub-humid region of Chhattisgarh has a long summer period and short winter with average ambient temperature ranging from $30^{\circ} \mathrm{C}$ to 
$45^{\circ} \mathrm{C}$ [31], which favored bacterial growth. These environmental conditions are not suitable for exotic breeds from temperate regions and, therefore, can adversely affect reproductive efficiency of Jersey bulls. Hence, these adverse conditions might lead stress in Jersey bulls resulting reduction in resistance against infection, thus favoring the proliferation of the bacterial population. However, crossbred cattle (HF cross) are well-adapted to the local hot and humid climatic conditions [32]. Decreases in semen quality were less severe, occurred later, and recovered more rapidly in crossbred bulls than in exotic bulls exposed to high ambient temperatures [33]. Thus, a continuous evaluation of their semen quality is required to achieve higher non-return rates and also to keep the crossbreeding program economically viable. On other hand, indigenous breeds are well known for their heat tolerance, resistance to various diseases, adaptability to atmospheric changes [34], these facts were supported by Tarate et al. [35] and Katariya [36], who observed higher somatic cell count in milk of crossbred cattle as compared to indigenous breed.

\section{Influence of age on bacterial load}

Comparatively, higher bacterial load in semen of young and older bulls are supported by Brown et al. [11] and Almquist et al. [4], respectively. Bacterial load observed by Brown et al. [11] for bulls aged 2, 3, $5,6,8$ and 10 years were $5.3 \times 10^{4}, 4.5 \times 10^{3}, 8.1 \times 10^{3}$, $3.7 \times 10^{3}, 4.4 \times 10^{3}$ and $5.7 \times 10^{3} \mathrm{CFU} / \mathrm{ml}$ respectively. Relatively higher bacterial load in young and old aged bulls could be attributed to poor immune system of those animals, making the bulls more prone to infection. On contrary, in an investigation [37] higher bacterial load was reported in middle-aged camels (9-13 years) than young (4-8 years) and old aged (14-18 years) animals.

\section{Conclusion}

Bacterial load was evaluated in semen of six breeds of cow and one breed of buffalo bull belonging to various age groups and a comparative analysis was made between species, breeds, and age groups. Despite of variation of bacterial load in bovine and bubaline semen, no significant differences were measured between species. However, bacterial load between breeds varied significantly and significantly higher bacterial load was observed in semen of Jersey bull followed by cross-bred animals and indigenous cattle breeds. Higher bacterial count was reported in young and old bulls, but differences measured were non-significant.

\section{Authors' Contributions}

CS and AN designed the experiment. Sample collection and preparation of frozen semen straws was performed by SBS, CS, and AN under supervision of SAS. Sample processing, overall experiment and statistical analysis were done by $\mathrm{CS}, \mathrm{AK}, \mathrm{AKG}$, and RKS under supervision of SAS. Manuscript preparation was reviewed and edited by all authors. All authors read and approved the final manuscript.

\section{Acknowledgments}

The authors are highly thankful to the Director, Veterinary Services, Government. of Chhattisgarh for providing necessary facilities and fund during this study.

\section{Competing Interests}

The authors declare that they have no competing interests.

\section{References}

1. Vinodh, R., Raj, G.D., Govindrajan, R. and Thiagarajan, V. (2007) Detection of Leptospira and Brucella genomes in bovine semen using polymerase chain reaction. Trop. Anim. Health Prod., 5: 11250-11257.

2. Diemer, T., Weidner, W., Michelmann, H.W., Sciefer, H.G., Rovan, E. and Mayer, F. (1996) Influence of Escherichia coli on motility parameters of human spermatozoa in vitro. Int. J. Androl., 19 (5): 271-277.

3. Griveau, J.F., Domount, E., Renard, P., Challegani, J.P. and Lelannou, D. (1995) Reactive oxygen species lipid peroxidation and enzymatic defense system in human spermatozoa. J. Reprod. Fertil., 103 (1): 17-26.

4. Almquist, J.O., Prince, P.W. and Ried, J.J. (1949) Bacteriological studies of bovine semen. i. numbers of bacteria and the relation to fertility. J. Dairy Sci., 32 (6): 543-548.

5. Jasial, S., Katoch, R.C., Chachara, D. and Mahajan, A. (2000) Evaluation of bacterial load in fresh ejaculates of bovine and buffalo bull semen in Himachal Pradesh. Indian J. Anim. Sci., 70: 465-467.

6. Patel, H.V., Patel, R.K. and Chauhan, J.B. (2011) Biochemical properties of microbial load in frozen semen of cattle. Wayamba J. Anim. Sci., 3: 117-121.

7. Panchal, SP., Pathak, V. and Patel, R.K. (2012) Estimation of microbial load and their biochemical properties in frozen semen doses of Murrah buffalo bulls. Wayamba J. Anim. Sci., 4: 356-366.

8. Shukla, M.K. (2005) Correlation of microbial load of cryopreserved semen with quality of neat and cryppreserved murrah buffalo bull semen. Buffalo Bull., 24: 84-87.

9. Rana, N., Vaid, R.K., Phulia, S.K. and Sigh, P. (2012) Assessment of bacterial diversity in fresh bubaline semen. Indian J. Anim. Sci., 82 (6): 596-598.

10. Rathnamma, D., Rao, M.S., Ramanatha, K.R. and Raghavan, R. (1997) Assessment of bacterial load in semen of HF bulls. Curr. Res. Univ. Agric. Sci. Bangalore, 26: 205-207.

11. Brown, V.G., Schollum, L.M. and Jarvys, B.D.W. (1974) Microbiology of bovine semen and artificial breeding practices under Newzealand condition. New Zeal. J. Agric. Res., 17: 431-442.

12. Hasan, S., Andrabi, S.M.H., Muneer, R., Anzar, M. and Ahmed, N. (2001) Effects of a new antibiotic combination on post thaw motion characteristics and membrane integrity of buffalo and Sahiwal bull spermatozoa and on the bacteriological quality of their semen. Pak. Vet. J., 21 (1): 6-12.

13. NDDB (2012) National Dairy Plan Phase I. Manual on. Semen Production. Project Implementation Plan: Vol. IV C. Project Management Unit. (located in NDDB). Available from: http://www.nddb.coop/ndpi/English/ AboutNDPI/Manuals-Guidelines/PDFDocuments/ PIP-Vol-IV-C-Manual-on-Semen-Production.pdf Last accessed on 28-10-2014.

14. Shukla, M.K. (2008) Minimum standard protocols for frozen 
semen production. In: Refresher Training on Diagnostic and Therapeutic Skill Of Bovine Reproductive Problems. Department of Animal Reproduction, Gynaecology and Obstetrics, SDAU, SK Nagar.

15. Akhter, S., Ansari, M.S., Andrabi, S.M.H., Ullah, N. and Qayyum, M. (2008) Effect of antibiotic in extender on bacterial and spermatozoal quality of cooled buffalo (Bubalus bubalis) bull semen. Reprod. Domest. Anim., 43 (3): 272-278.

16. Shukla, M.K., Bansal, R. and Dhumatkar, O. (2011) Applied Veterinary Andrology and Frozen Semen Technology. New India Publishing Agency, New Delhi.

17. Gunsalus, I.C., Salisbury, G.W. and Willet, E.L. (1941) The bacteriology of bull semen. J. Dairy Sci., 24: 911-919.

18. Meredith, M.J. (1970) Bacterial count of semen collected by artificial vagina, from bulls that evert the prpeutial epithelium. Vet. Rec., 87 (5): 122-124.

19. Miller, J.C. and Salisbury, G.W. (1939) Conference on artificial insemination. J. Anim. Sci., 1: 208-213.

20. Yaniz, J.L., Marco-Aguado, M.A., Mateos, J.A. and Santolaria, P. (2010) Bacterial contamination of ram semen, antibiotic sensitivities, and effects on sperm quality during storage at $15^{\circ}$ C. Anim. Reprod. Sci., 122 (12): 142-149.

21. Kumar, A.G., Raju, P.V., Prabhakaran, N.K., Kumar, G.A. and Nair, K.P. (1994) Type of bacteria and its load in fresh semenof cross - Bred bulls. Indian J. Anim. Reprod., 15: 48-49.

22. Wierzbowski, S., Nowakowski, W., Wayda, E. and Kuzniak, S. (1984) Antibiotic level and bacterial contamination of frozen bull semen (Streptomycin, Penicillin). Med. Weter., 40 (5): 284-287.

23. Bugalia, N.S., Gulati, indeWrjeet, garg, B.R. and Verma, S.K. (1998) Thyroid function, testosterone profiles and preputial microbes in cow and buffalo bulls. Indian J. Anim. Sci., 68 (4): 341-343.

24. Pal, A., Chatterjee, P.N. and Chakravarty, A.K. (2012) Genetic study of dairy cattle and buffalo bulls based on growth, milk production and reproductive traits. Iran. J. Appl. Anim. Sci., 2 (3): 239-245.

25. Patel, D.Y. and Patel, R.K. (2012) Estimation of biochemical activities of microbial load isolated from the frozen semen of HF and HF crossbred cattle bulls. Curr Trends Biotechnol Pharm., 6 (3): 328-339.

26. Bhatt, V.P., Khade, P.S., Tarate, S.B., Tripathi,A.K., Nauriyal, D.S., Rank, D.N., Kunjadia, A.P. and Joshi, C.G. (2012)
Cytokine expression pattern in milk somatic cells of subclinical mastitis affected cattle analyzed by real time PCR. Korean J. Vet. Res., 52 (4): 231-238.

27. Perumal,P.,Kumar,K.T. andSrivastava,S.K.(2013)Infectious causes of infertility in buffalo bull (Bubalus bub alis). Buffalo Bull., 32 (2): 71-82, 96.

28. Gaur, G.K., Kaushik, S.N. and Garg, R.C. (2003) The gir cattle breed of India: Characteristics and present status. Anim. Genet. Resour. Inf., 33: 21-29.

29. Bava, L., Sandrucci, A., Tamburini, A., Brasca, M., Vanoni, L. and Zucali, M. (2011) Milk hygiene at the farm: Effects of management and environmental factors. Sci Tecnica Lattiero-casearia, 62: 75-84.

30. Baron, S. (2004) Medical Microbiology. Texas University, Medical branch, Galveston, TX. p312-344.

31. National Horticulture Commission. (2013) Report of the Joint Inspection Team on their inspection visit to (Durg, Bilaspur, Korba, Raigarh) Districts of Chhattisgarh during November, 2013 (2 $2^{\text {th }}$ Nov-30 $0^{\text {th }}$ Nov, 2013) nhm nic. in/ JIT-Reports/JIT-chhattisgarh-201314.pdf.

32. Anjum, I.A., Usmani, R.H., Tunio, M.T. and Abro, S.H. (2009) Improvement of conception rate in crossbred cattle by using GnRH analogue therapy. Pakistan Vet. J., 29: 93-94.

33. Johnston, J.E., Naelapaa, H. and Frye, J.B. (1963) Physiological responses of holstein, brown swiss and red sindhi crossbred bulls exposed to high temperatures and humidities. J. Anim. Sci., 22: 432-436.

34. Wondifraw, Z., Thombre, B.M. and Bainward, D.V. (2013) Effect of nongenetic factors in milk production of HF X Deoni crossbred cows. Int. J. Livest. Prod., 4 (7): 106-112.

35. Tarate, S.B., Jadhav, P.V., Ghdigaon Kar, D.D., Khade, P.S., Bhatt, V.D. and Khan, A.A. (2012) Evaluation of breed dependent variation in microbial load during subclinical mastitis in cattle using Real time PCR. Indian J. Anim. Sci., 65 (1): 60-65.

36. Katariya, A.K. and Katariya, N. (2006) A comparison of somatic cell count in milk from Rathi and HF cattle. Indian Cow Sci. Econ. J., 3 (10): 3-5.

37. Ghoneim, I.M., Waheed, M.M., Al-hofofi, A.N., Fayez, M.M., Al-Eknah, M.M., Al-Busadah, K.A. and Al-humam, N.A. (2014) Evaluation of microbial quality of fresh ejaculates of camel (Camelus dromedaries) semen. Anim. Reprod. Sci., 149 (3-4): 218-223.

\section{$* * * * * * * *$}

